\title{
X-linked Lymphoproliferative Syndrome
}

\author{
NATURAL HISTORY OF THE IMMUNODEFICIENCY
}

\author{
John L. Sullivan, Kevin S. Byron, Frank E. Brewster, Sharon M. Baker, and \\ Hans D. OChS, Department of Pediatrics, University of Massachusetts \\ Medical School, Worcester, Massachusetts 01605; Department of Pediatrics, \\ University of Washington, Seattle, Washington 98195
}

A B S T R A C T The X-linked lymphoproliferative syndrome is characterized by immunodeficiency to Epstein-Barr virus (EBV) manifested by severe or fatal infectious mononucleosis and acquired immunodeficiency. We studied immune responses in six males of a well-characterized kindred with the X-linked lymphoproliferative syndrome. Two males were studied before and during acute fatal EBV infection. Both individuals demonstrated normal cellular and humoral immunity before EBV infection. During acute EBV infection, both individuals developed vigorous cytotoxic cellular responses against EBV-infected and -ưnninfected target cells. Anomalous killer and naturál killer $\mathrm{T}$ cell activity was demonstrated against a va'riety of lymphoid cell lines, autologous fibroblasts and autologous hepatocytes. Effector cells responsible for anomalous killing reacted with a pan- $\mathrm{T}$ cell monoclonal antibody, and belonged to the OKT.8 $\mathrm{T}$ cell subset. Death in each case was caused by liver failure, but one patient developed extensive liver necrosis, whereas the other developed a massive infiltration of the liver with EBV-infected immunoblasts after aggressive immunosuppressive therapy. Immunological studies were performed on four males who had survived EBV infection years previously. They demonstrated global cellular immune defects with deficiencies of lymphocyte proliferative responses to mitogens and antigens, humoral immune deficiencies, abnormalities of regulatory $T$ cell subsets and deficient natural killer cell activity. We propose that an aberrant immune response triggered by acute EBV infection results in unregulated anomalous killer and natural killer cell activity against EBV infected and uninfected cells. These studies suggest that global immune defects appearing in males with $\mathrm{X}$-linked lymphopro-

Received for publication 13 October 1982 and in revised form 24 January 1983. liferative syndrome who survive EBV infection are epiphenomenon.

\section{INTRODUCTION}

The importance of understanding the mechanisms responsible for the control of Epstein-Barr virus (EBV) ${ }^{1}$ infection in man have been highlighted by clinical observations reported in recent years. In 1974 and 1975, three families were described in which an $\mathrm{X}$-linked immunodeficiency to EBV resulted in fatal infectious mononucleosis in affected male members $(1-3)$. Studies of these families with the X-linked lymphoproliferative syndrome (XLP) have demonstrated that fatal infectious mononucleosis, acquired immunodeficiency and lymphoproliferative disorders occur with high frequency in males experiencing EBV infection (4). Approximately $70 \%$ of affected males die with a fatal infectious mononucleosis syndrome with severe hepatitis and liver failure accounting for mortality in many cases. The majority of males who survive their initial encounter with EBV develop an immunodeficiency disorder characterized by hypogammaglobulinemia and recurrent infections. Prospective immunological studies have not been reported in wellcharacterized kindreds with XLP. We have studied six members of a previously reported family (5) who illustrate the natural history of the immunodeficiency observed in males affected with XLP. In this kindred, 20 males have been affected with XLP (5). Two mem-

\footnotetext{
${ }^{1}$ Abbreviations used in this paper: AK, anomalous killer; anti-Ig, anti-immunoglobulin-coated beads; Con A, concanavalin A; EA, early antigen; EBNA, Epstein-Barr nuclear antigen; EBV, Epstein-Barr virus; LCL, lymphoblastoid cell lines; MLR, mixed lymphocyte reaction; NK, natural killer; PHA, phytohemagglutinin; PWM, pokeweed mitogen; SGOT, serum glutamic oxaloacetic transaminase; VCA, viral capsid antigen; XLP, X-linked lymphoproliferative syndrome.
} 
bers of this family were studied before their encounter with EBV and during the acute phase of a fatal EBVinduced illness. Functional $\mathrm{T}$ lymphocytes and natural killer-cell populations were present before acute illness. Vigorous killer-cell activity accompanied acute exposure to EBV. Death in each case was primarily due to liver failure. Four males who survived their acute EBV infection were studied and demonstrated abnormal $\mathrm{T}$ cell and natural killer (NK) cell function. We propose that defective regulation of cytotoxic responses triggered by EBV-infected B cells results in fatal infectious mononucleosis or, in those who survive, immune deficiency.

\section{METHODS}

\section{Patients}

Each patient studied is a member of a well-characterized kindred with the XLP described by Purtilo et al. (5) in 1977.
An updated pedigree is shown in Fig. 1 and the patients included in this report are indicated. Informed consent was obtained from each patient or their parents. All studies were carried out with the approval of the Human Subjects Review Committee at the University of Massachusetts Medical School.

\section{Fatal cases}

Case 1 (V-38). This 27-mo-old white male was admitted to the hospital with the diagnosis of infectious mononucleosis (Fig. 1). On arrival, the patient had a temperature of $38.6^{\circ} \mathrm{C}$ with a maculopapular rash on his trunk and extremities. He had marked anterior, posterior cervical, and supraclavicular lymphadenopathy. The liver extended $3 \mathrm{~cm}$ below the right costal margin, the spleen extended $2 \mathrm{~cm}$ below the left costal margin. A complete blood count revealed atypical lymphocytes (13\%). A lymph node biopsy demonstrated EpsteinBarr nuclear antigen (EBNA)-positive cells on a touch preparation. EBV serology showed IgM and IgG antibody against EBV capsid antigen (IgM-VCA 1:320; IgG-VCA 1:80). The patient was treated with acyclovir therapy as previously reported (6). Over the first days of therapy, the patient con-

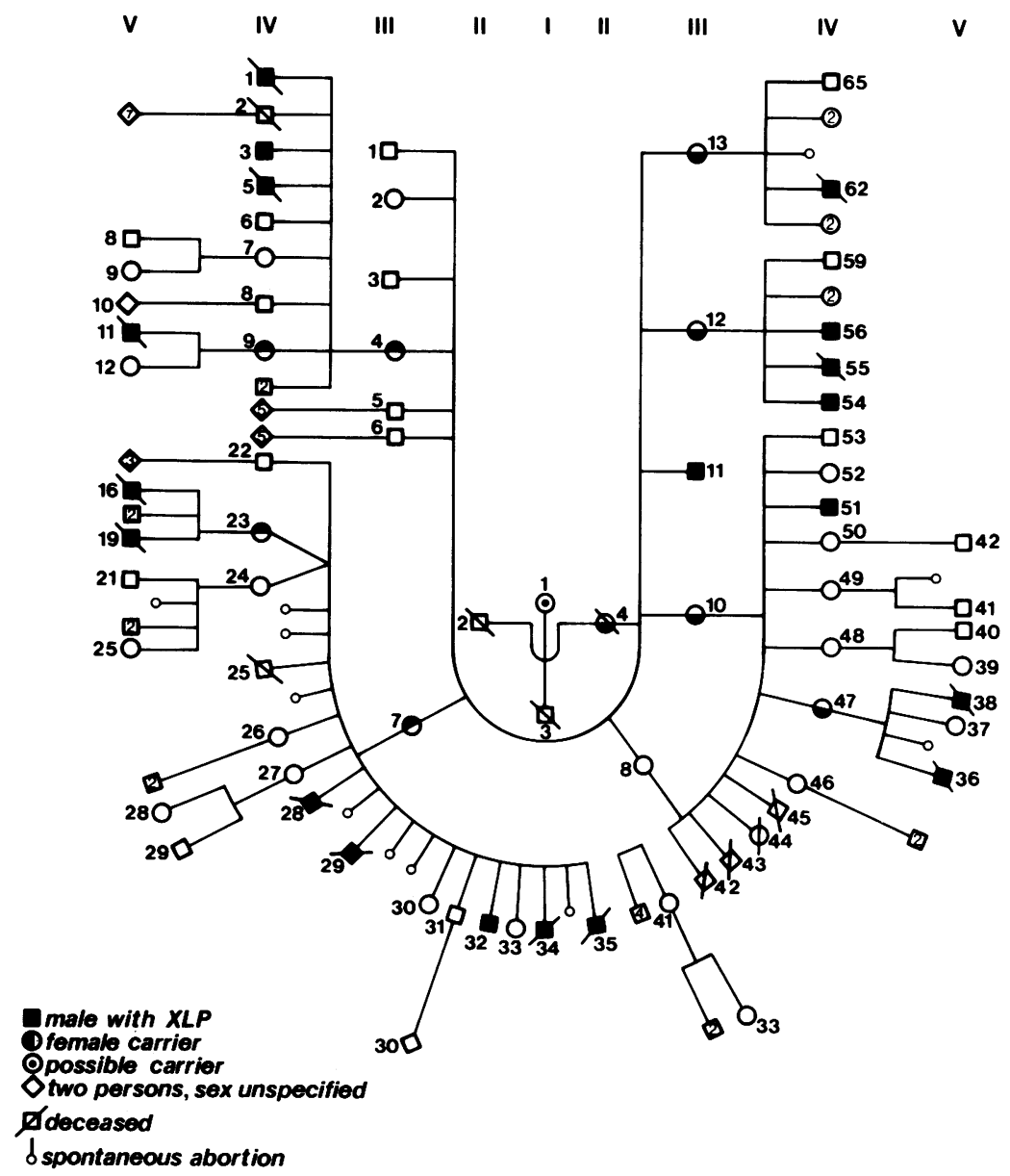

FIGURE 1 Pedigree of a family with XLP; the family history is detailed by Purtilo et al. (5). 
tinued to have a marked fever, irritability, and persistence of maculopapular rash on the trunk and extremities. Atypical lymphocytosis persisted in the range of 25 to $40 \%$. On the seventh day of hospitalization, because of persistent fever, increasing hepatomegaly, and worsening liver function tests (serum glutamic oxaloacetic transaminase [SGOT], 145 IU), $0.9 \mathrm{mg} / \mathrm{kg}$ of gamma globulin with an EBV capsid antibody titer $>1: 1,000$ was given intramuscularly. Over the next 3 $\mathrm{d}$, the patient improved clinically and the rash began to fade. The fever persisted, however, and his liver function studies continued to deteriorate (SGOT, 1,050). On the 11th hospital day, the patient was jaundiced, liver was enlarged to $5 \mathrm{~cm}$ below the right costal margin and the SGOT was $>3,000$. At this time, the patient received $200 \mathrm{~cm}^{3}$ of fresh frozen plasma obtained from an EBV seropositive donor. On the 12th hospital day, the liver failure worsened and because immunological studies suggested an autoaggressive hepatitis, the patient was begun on methylprednisolone $6 \mathrm{mg} / \mathrm{kg}$ per $\mathrm{d}$ in divided doses. Over the next $3 \mathrm{~d}$, the patient progressively deteriorated and on the 15th day of hospitalization, the patient lapsed into a coma and expired on the 16th hospital day

At autopsy, the lymphoid system showed widespread necrosis with infiltration by immunoblasts and plasma cells. The thymus was depleted and contained rare multinucleated giant cells. A mononuclear cell infiltrate was present in the myocardium, peribronchial areas of the lung, and portal areas of the liver. Marked necrosis of the liver was present and death was attributed to fulminant liver failure.

Case $2(V-19)$. A 10-yr-old white male was admitted to the hospital with the diagnosis of infectious mononucleosis. This patient had a history of a lymphoma of the liver, diagnosed at age $3.5 \mathrm{yr}$. The tumor was diagnosed as a lymphosarcoma and the patient was treated initially with vincristine, cyclophosphamide, and prednisone with cyclophosphamide, and prednisone maintenance. His last chemotherapy was at age $6 \mathrm{yr}$. He had been hospitalized on occasion for pneumonia and was diagnosed as having bronchiectasis of the left lower lobe. The patient was admitted with a $7-d$ history of fever, cough, headache, and abdominal pain. Elevated liver enzymes (SGOT 330), atypical lymphocytosis, and positive heterophile antibody suggested acute EBV infection, which was confirmed by EBV-specific serology demonstrating the presence of IgM antibody against EBV capsid antigen. Immunological studies demonstrated vigorous killer-cell activity against a panel of EBV infected and noninfected target cells. Because of the previous experience with case 1 , it was decided to combine immunosuppressive therapy (methylprednisolone) and antiviral therapy (acyclovir). Acyclovir therapy was given at a dose of 500 $\mathrm{mg} / \mathrm{m}^{2}$ every $8 \mathrm{~h}$ combined with methylprednisolone 5 $\mathrm{mg} / \mathrm{kg}$ per $\mathrm{d}$ in three divided doses. During the first several days of therapy, the patient's rash faded, temperature dropped toward normal and the SGOT (141) began to fall. A leukocytosis with marked atypical lymphocytes (45\%) persisted. The patient received 1 unit of plasma obtained from his mother, which contained high titers of antibodies to VCA, early antigen (EA), and EBNA. On day 7 of hospitalization, he was still irritable and the SGOT (303) began to rise. Methylprednisolone was increased to $10 \mathrm{mg} / \mathrm{kg}$ per $\mathrm{d}$ in four divided doses. On day 8 , the patient remained irritable and the SGOT increased further. Antithymocyte globulin (ATG) (ATGAM, Upjohn Pharmaceutical Co., Kalamazoo, MI) was administered because immunological studies performed on day 5 and day 7 showed moderate levels of cytotoxic T lymphocytes to be present in the circulation. ATG was begun at $15 \mathrm{mg} / \mathrm{kg}$ per $\mathrm{d}$ in a single daily intravenous dose. Over the next week, his condition deteriorated, he became febrile, and liver function tests demonstrated severe hepatitis. On the 13th hospital day, pneumococcal bacteremia was diagnosed and treated with antibiotics. His clinical condition continued to deteriorate over the next $2 \mathrm{~d}$; he became jaundiced, and expired on day 15 with fulminant liver failure.

An autopsy showed widespread evidence of lymphoproliferation. The liver was enlarged and massively infiltrated with immunoblasts consistent with the diagnosis of immunoblastic sarcoma. Liver necrosis was also present, but to a lesser degree than observed in case 1 .

\section{Males surviving acute EBV infection}

Case 3 (IV-32). A 21-yr-old male experienced an illness compatible with mononucleosis at age $10 \mathrm{yr}$. After this illness, the patient suffered repeated pulmonary infections. At age 17 , he was found to be hypogammaglobulinemic and begun an intramuscular gamma globulin therapy. Over the past $4 \mathrm{yr}$, the patient has been free of significant pulmonary infections.

Case $4(I V-51)$. This 21-yr-old male was well until 6 mo of age when he developed a syndrome characterized by fever, pneumonia, and hepatosplenomegaly. He was hospitalized and during the first week of illness, he became more severely ill and developed aseptic meningitis and anterior uveitis. His leukocyte count ranged from 6,000 to 22,000 $\mathrm{mm}^{3}$ with many atypical lymphocytes and he was severely anemic with a hematocrit of 18. A heterophile antibody titer was negative. Bone marrow examination revealed infiltrating lymphocytes and a liver biopsy revealed periportal lymphoid infiltrations. During his hospitalization, he was initially treated with broad spectrum antibiotics and later corticosteroids. Over a 3-wk period, his illness gradually resolved and he was discharged to home. From this period on, the patient suffered recurrent bouts of suppurative otitis media and bacterial pneumonia. At age 16, the patient was found to have severe bronchiectasis and hypogammaglobulinemia. Immunoglobulin levels were IgG, $89 \mathrm{mg} / \mathrm{dl}$; IgA, $23 \mathrm{mg} / \mathrm{dl}$; IgM, $57 \mathrm{mg} / \mathrm{dl}$. The patient was begun on intramuscular gamma globulin therapy and over the past $5 \mathrm{yr}$, he has been clinically well with occasional minor illnesses.

Case 5 (IV-54). A 23-yr-old white male was diagnosed as having a lymphoma of the ileum at age 12 , which was treated with surgery and radiation. He has completely recovered and has not suffered any serious bouts with infections.

Case 6(IV-56). A 15-yr-old white male experienced acute EBV infection at age 10, which was manifested by mild lymphadenopathy, rash, and sore throat. Hypogammaglobulinemia was discovered at the time of his acute infection. He has remained mildly hypogammaglobulinemic but has not suffered any significant recurrent infections.

\section{Cell preparations}

Peripheral blood mononuclear cells (PBMC) were obtained from heparinized venous blood and separated by Ficoll-Hypaque (Pharmacia Fine Chemicals, Inc., Piscataway, $\mathrm{NJ}$ ) density-gradient centrifugation. PBMC were cultured in Hepes-buffered RPMI 1640 medium supplemented with $20 \%$ fetal calf serum (FCS), $100 \mathrm{U} / \mathrm{ml}$ penicillin, and 100 $\mu \mathrm{g} / \mathrm{ml}$ streptomycin. PBMC preparations contained $70-80 \%$ lymphocytes, $10-20 \%$ monocytes, and $<20 \%$ polymorphonuclear leukocytes as determined by cell morphology. Cell viability was assessed by $0.5 \%$ trypan blue exclusion. Hepatic 
epithelial cell monolayers were prepared by established methods (7). Collagenase-dispersed cells were cultured in Ham's F-12 medium supplemented with $10 \%$ FCS and a mix of insulin, transferrin, and selenium (Collaborative Research Inc., Waltham, MA). Cells were cultured for $7 \mathrm{~d}$ before use as target cells in the cytotoxicity assay. Examination by phase-contrast microscopy was consistent with epithelial cells with a granular cytoplasm. No lymphoid cells were present at this time.

Bulk $\mathrm{T}$ cell cultures were prepared by placing 0.5-1.0 $\times 10^{6} \mathrm{PBMC}$ in $2 \mathrm{ml}$ of medium containing $30 \%$ purified lectin-free $\mathrm{T}$ cell growth factor (provided by Dr. Kendall A. Smith, Dartmouth Medical School, Hanover, NH). T cell growth was monitored with the use of an inverted microscope and bulk cultures were analyzed by morphology, staining reactions with monoclonal antibodies, and functional studies.

Some studies were performed on cryopreserved PBMC that were frozen using a Planer controlled rate cell freezer (Planer mini-freezer, model R202/200R, Polaron Instruments, Inc., Doylestown, PA).

\section{Surface marker analysis}

PBMC were analyzed for the following surface markers: E-rosette formation, C3-rosette formation, Fc receptors, and surface membrane $\operatorname{Ig}(8)$. T cell populations were enumerated using indirect immunofluorescence and the monoclonal antibodies T101 (pan T cell, Hybritech, Inc., La Jolla, CA); OKT.4 (T helper/inducer), OKT.8 (T cytotoxic/suppressor) OKM.l (monocytes and NK cells) (Ortho Pharmaceutical, Raritan, NJ); and Leu-7 (HNK.1, NK cell) (Becton, Dickinson \& Co., Sunnyvale, CA). HLA-DR antigens were defined using heterologous antisera directed against a common HLA-DR determinant (anti-p23,30; kindly provided by Dr. Robert Humphreys, University of Massachusetts Medical School, Worcester, MA).

\section{Lymphocyte proliferation studies}

A standard microculture method was used (9). PBMC containing lymphocytes and were distributed in Microtiter II plates (Falcon Labware, Div. of Becton, Dickinson \& Co., Oxnard, CA); replicate wells contained $5 \times 10^{4}$ cells for mitogen experiments, and $10^{5}$ cells for anti-Ig and mixed leukocyte cultures in $0.2 \mathrm{ml}$ of RPMI containing $10 \%$ FCS. Mitogens were added in the following concentrations: phytohemagglutinin (PHA, Burroughs Wellcome, Research Triangle Park, NC) 0.1-2.0 $\mu \mathrm{g} /$ culture; pokeweed mitogen (PWM, Gibco Laboratories, Grand Island, NY) 0.1-10 $\mu \mathrm{g}$ / culture; concanavalin A (Con A, Calbiochem-Behring Corp., American Hoechst Corp., San Diego, CA) 0.1-3.0 $\mu \mathrm{g} / \mathrm{cul}$ ture. Cultures were terminated on day 3 for PHA, day 5 for Con A and PWM. Antiimmunoglobulin-coated beads (antiIg) (provided by Dr. David Parker, University of Massachusetts Medical School, Worcester, MA) were used at a concentration that formed a single layer completely covering the bottom of the microtiter well (10) and cultures were terminated on day 3. Mixed leukocyte reactions (MLR) were carried out using a B-lymphoblastoid cell line (LCL) as a stimulator cell (11).

All cells were cultured in a $5 \% \mathrm{CO}_{2}$ environment at $37^{\circ} \mathrm{C}$. $18 \mathrm{~h}$ before harvesting, the cultures were pulsed with $2 \mu \mathrm{Ci}$ of $\left[{ }^{3} \mathrm{H}\right]$ thymidine $\left[{ }^{3} \mathrm{H}\right] \mathrm{TdR}$; sp act $6.7 \mathrm{Ci} / \mathrm{mM}$; New England Nuclear, Boston, MA). Cells were harvested onto glass-fiber filters and $\left[{ }^{3} \mathrm{H}\right]$ thymidine content determined by scintillation spectrometry. All cultures were performed either in triplicate or replicates of six.

\section{Statistical analysis}

Logarithmic transformation of the data was used for calculation of the means, variance, standard deviation, and the $t$ statistic. These are expressed as geometric means, $95 \%$ confidence intervals, and coefficients of variations and $P$ values.

\section{Cytotoxicity studies}

Cell-mediated cytotoxicity was determined against EBVinfected and NK-sensitive target cells $(12,13)$. Target cells consisted of cell lines 8392 and 8402 for EBV-specific cytolysis (11). NK cell targets consisted of cell line K562, Daudi, and herpes simplex virus-infected fibroblasts $(13,14)$. In selected experiments, target cells consisted of spontaneous and/or B95-8 EBV-induced B LCL. The cytotoxicity assay is a modification of a 4 -h sodium ${ }^{51} \mathrm{Cr}$-chromate release assay described previously (12). Briefly, effector cells were placed in round-bottom wells of a microtiter tray with $1 \times 10^{451} \mathrm{Cr}$ labeled target cells at effector-to-target ratios ranging from $10: 1$ to $50: 1$ in $0.2 \mathrm{ml}$ of RPMI 1640 and $10 \%$ FCS. The tray was spun at $200 \mathrm{~g}$ for $5 \mathrm{~min}$, incubated for $4 \mathrm{~h}$ at $37^{\circ} \mathrm{C}$ in $5 \% \mathrm{CO}_{2}$ atmosphere and then centrifuged at $200 \mathrm{~g}$ for $5 \mathrm{~min}$. Aliquots $(0.1 \mathrm{ml})$ of the supernatant were removed, placed in glass tubes and counted in a gamma counter. The percentage of specific lysis was calculated by the formula: ([experimental cpm - spontaneous cpm]/[maximal cpm - spontaneous cpm]) $\times 100 \%$.

\section{Bacteriophage $\phi X 174$ studies and antibody determinations}

Bacteriophage $\phi \times 174$ was prepared as previously described (15) and given intravenously in a dose of $2.0 \times 10^{9}$ plaque-forming units/ $\mathrm{kg}$ body wt. The secondary immunization was carried out $6 \mathrm{wk}$ after the primary immunization. Antibodies to bacteriophage were determined by phage neutralization and expressed as the rate of inactivation of $K$ value $\left(K_{v}\right)$, as devised by a standard formula (15). Isohemagglutinin titers were determined in the University of Massachusetts Medical Center Blood Bank. Quantitative immunoglobulins were determined by standard radial immunodiffusion or nephelometric techniques. Pneumococcal capsular polysaccharide antibodies were determined by a sensitive radioimmunoassay (16). Viral antibodies (excluding EBV) were determined at the Massachusetts State Laboratory, Jamaica Plain, MA.

Antibody titers to EBV-VCA, EA, and EBNA were determined by established methods $(17,18)$. In each of these assays, EBV-uninfected cell lines served as controls for nonspecific fluorescence. Known positive and negative control sera were tested in parallel.

\section{EBV studies}

Spontaneous and B 95-8 LCL were established as previously described (19). Touch preparations made from lymphoid tissues obtained at autopsy were fixed in acetone/ methanol and stained for the presence of EBNA by the method of Reedman and Klein (18). Productive virus infection was tested by collecting supernatants from spontaneous LCL and incubating these with cord blood lymphocytes. 
Cultures were observed weekly for 6 wk for evidence of transformation to an EBNA-positive LCL.

\section{RESULTS}

\section{Studies in males before and during fatal $E B V$ infection}

Immunological studies. Table I summarizes cellular and humoral immune studies on cases 1 and 2 before infection with EBV and during acute EBV infection. Both individuals demonstrated normal numbers of $\mathrm{T}$ and $\mathrm{B}$ lymphocytes before EBV infection. Functional studies demonstrated normal lymphocyte proliferative responses to the mitogens PHA, Con A, and PWM to streptolysin $\mathrm{O}$ and allogeneic antigens. Humoral immune function was normal as demonstrated by normal quantitative immunoglobulins, B lymphocyte numbers, and proliferative responses to anti-Ig. In addition, case 1 had a nonreactive Schick test, normal isohemagglutinin titers, normal response to rubella immunization, and circulating antibodies to several pneumococcal polysaccharide serotypes. NK cell activity against the K562 cell line was assessed in case 2 before infection and found to be normal.

Both case 1 and case 2 demonstrated suppressed responses to mitogens and antigens during acute EBV infection, which is typical of normal individuals experiencing acute infectious mononucleosis (21). Marked increases in serum IgM levels were also observed. Cytotoxicity for the EBV-infected B lymphoblastoid cell line 8392 and the NK-sensitive target K562 was present in each case during the acute EBV infection. Table II summarizes cytotoxic studies performed during acute EBV infection. Each patient demonstrated vigorous cytotoxic responses against a panel of cell lines that are susceptible to lysis by NK cells and EBV-induced cytotoxic T cells. Cell lines K562 and Daudi are susceptible NK targets. Cell line 8392 is an EBV-infected $B$ LCL that is lysed by cytotoxic $T$ cells present in the acute phase of EBV-induced infectious mononucleosis (12). These EBV-specific killer cells are not restricted

TABLE I

Immunological Assessment before and during Acute EBV Infection in Two Males with XLP

\begin{tabular}{|c|c|c|c|c|c|}
\hline & \multicolumn{2}{|c|}{ Before infection } & \multicolumn{2}{|c|}{ During infection } & \multirow[b]{2}{*}{ Normal values } \\
\hline & $\begin{array}{c}\text { Case } 1 \\
\text { Age } 1.5 \mathrm{yr}\end{array}$ & $\begin{array}{l}\text { Case } 2 \\
\text { Age } 8 \text { yr }\end{array}$ & $\begin{array}{c}\text { Case } 1 \\
\text { Age } 2.1 \mathrm{yr}\end{array}$ & $\begin{array}{l}\text { Case } 2 \\
\text { Age } 11 \mathrm{yr}\end{array}$ & \\
\hline \multicolumn{6}{|c|}{ Lymphocyte surface markers $(\%)^{\circ}$} \\
\hline T lymphocytes & 68 & 63 & 65 & 64 & $65.0 \pm 2.9$ \\
\hline B lymphocytes & 11 & 8 & 6 & 16 & $10.5 \pm 0.7$ \\
\hline \multicolumn{6}{|c|}{$\begin{array}{l}\text { Quantitative immunoglobulins } \\
\qquad(\mathrm{mg} / 100 \mathrm{ml})\end{array}$} \\
\hline IgG & 540 & 1,430 & 700 & 1,825 & $423-1,657$ \\
\hline $\operatorname{Ig} A$ & 88 & 348 & 191 & 693 & $27-472$ \\
\hline IgM & 48 & 270 & 296 & 706 & $28-113$ \\
\hline \multicolumn{6}{|c|}{ Lymphocyte proliferation studies $\downarrow$} \\
\hline PHA & 94,037 & 110,352 & 13,077 & 4,292 & $71,450-82,414$ \\
\hline Con A & 53,861 & 206,950 & 1,995 & 1,242 & $81,847-106,414$ \\
\hline PWM & 41,618 & 64,135 & 2,857 & 1,706 & $27,164-38,194$ \\
\hline MLR & 188,570 & 169,384 & 17,152 & 11,148 & $153,460-181,134$ \\
\hline $\mathrm{S} / \mathrm{O}$ & 139,698 & 70,757 & 2,035 & 3,525 & $41,495-75,858$ \\
\hline Anti-Ig & ND & 4,758 & & 15,073 & $5,248-11,803$ \\
\hline \multicolumn{6}{|c|}{ Cytotoxicity studies $\S$} \\
\hline Target K562 & ND & $62 \%$ & $85 \%$ & $85 \%$ & $>50 \%$ \\
\hline 8392 & & $0 \%$ & $49 \%$ & $35 \%$ & $<10 \%$ \\
\hline
\end{tabular}

\footnotetext{
- T lymphocytes determined by E-rosettes or fluorescence with monoclonal pan-T cell antibody, T101; B lymphocytes determined by immunofluorescence with anti- $\mu$ heterologous antisera. Normal values represent mean \pm SE for 17 normal young adults.

† Results expressed as mean net counts per minute of triplicate cultures that showed maximal stimulation to graded doses of mitogens and antigens. MLR, using a B lymphoblastoid cell line as a stimulator; S/O, streptolysin $\mathrm{O}$; Normal values represent $95 \%$ confidence interval from 17 normal young adults. ND, not done.

\$ Cytotoxicity studies were performed at an effector-to-target cell ratio of 50:1 in a 4-h chromium release assay. Results are expressed as a cytotoxic index (Methods). K562 is a myeloid target sensitive to natural killer cell activity and 8392 is an EBV-infected B lymphoblastoid cell sensitive to EBV-specific T cell-mediated cytotoxicity.
} 
TABLE II

Cytotoxicity Studies during Acute EBV Infection in Two Males with XLP

\begin{tabular}{|c|c|c|c|c|c|c|c|c|}
\hline \multirow[b]{2}{*}{ Effector cells } & \multirow{2}{*}{$\begin{array}{l}\text { Day of } \\
\text { study }\end{array}$} & \multicolumn{7}{|c|}{ Target cells $^{\circ}$} \\
\hline & & K562 & Daudi & 8392 & 8402 & Allo LCL & Fib & HSV Fib \\
\hline \multirow[t]{4}{*}{ Case 1} & 1 & 85 & 61 & 49 & 22 & 82 & ND & ND \\
\hline & 6 & 88 & 21 & 21 & 21 & 60 & ND & ND \\
\hline & 12 & 81 & ND & 8 & 8 & 100 & ND & ND \\
\hline & 15 & 44 & ND & ND & ND & ND & ND & ND \\
\hline \multirow[t]{4}{*}{ Case 2} & 1 & 85 & 30 & 36 & 2 & 73 & 42 & 50 \\
\hline & 5 & 72 & 14 & 17 & 0 & 27 & 15 & 18 \\
\hline & 7 & 53 & ND & 3 & ND & 5 & ND & ND \\
\hline & 12 & 10 & ND & 6 & ND & 17 & ND & ND \\
\hline \multicolumn{9}{|l|}{ Infectious mononucleosis } \\
\hline$(n=5) !$ & & $84.2 \pm 4.4$ & ND & $38.4 \pm 11.4$ & $21.8 \pm 9.4$ & $43.8 \pm 22.9$ & $25.2 \pm 6.5$ & ND \\
\hline Normal controls $(n=12) \S$ & & $85.2 \pm 12.8$ & $24.8 \pm 7.7$ & $6.0 \pm 7.0$ & $4.1 \pm 5.1$ & $59^{\prime \prime}$ & $22^{\prime \prime}$ & $26^{\prime \prime}$ \\
\hline
\end{tabular}

- Target cells studied include: K562, myeloid cell line, a very sensitive NK target; Daudi, Burkitt's lymphoma line, mildly sensitive NK target; 8392, EBV-infected B LCL, relatively resistant to NK and sensitive to EBV-specific killer cells; 8402, a T LCL relatively resistant to NK and syngeneic to 8392; allo LCL, an EBV-infected B LCL sensitive to NK; Fib, allogeneic fibroblasts mildly sensitive to NK; HSV Fib, herpes simplex virus-infected fibroblasts mildly sensitive to NK. All results expressed as a cytotoxic index following a 4-h chromium release assay at an effector-to-target cell ratio of 50:1. ND, not done.

$\downarrow$ Five normal individuals with EBV-induced infectious mononucleosis, results expressed as mean \pm SD of cytotoxic indices; ND, not done. $\$ 12$ normal adults controls, results expressed as mean \pm SD of cytotoxic indices.

"Results of one normal control, mean cytotoxic index.

to EBV-infected target cells sharing HLA antigens (21). Each male with XLP showed vigorous lysis of 8392 and another recently established allogeneic lymphoblastoid cell line (allo LCL). The T cell line 8402, which is HLA-identical to 8392 , was not lysed to the same degree as the EBV-infected B cell line 8392. These data parallel those observed in individuals with acute infectious mononucleosis (12). In addition, normal cytotoxicity against primary fibroblast cells was observed in case 2.

Fig. 2 illustrates the change in NK activity during the course of each patient's illness. During the studies on case 1, we thought that anomalous killing (AK) might be responsible for the liver necrosis and an attempt to suppress this activity with high-dose methylprednisolone therapy $(5 \mathrm{mg} / \mathrm{kg}$ per d) was made. As demonstrated, a 3-d course of methylprednisolone resulted in a $50 \%$ decrease in cytotoxicity against the K562 target cells at a 50:1 effector-to-target cell ratio. However, a cytotoxic index of $45 \%$ was still observed on the last day of study. Case 2 was treated with methylprednisolone at a dose of $5 \mathrm{mg} / \mathrm{kg}$ per $\mathrm{d}$ in four divided doses. After $5 \mathrm{~d}$ of therapy killer cell activity remained with a cytotoxic index of $72 \%$. The dose of methylprednisolone was increased to $10 \mathrm{mg} / \mathrm{kg} / \mathrm{d}$ and killer-cell activity declined to $53 \%$ after $3 \mathrm{~d}$ at this dose. Liver enzymes that initially declined following steroid therapy increased and ATG at a dose of $15 \mathrm{mg} /$ $\mathrm{kg}$ per $\mathrm{d}$ once daily was added. After $5 \mathrm{~d}$ of ATG therapy, killer-cell activity declined to $10 \%$.

Cell surface markers studied during the course of infection in case 2 are shown in Table III. Initial studies before immunosuppressive therapy showed a marked

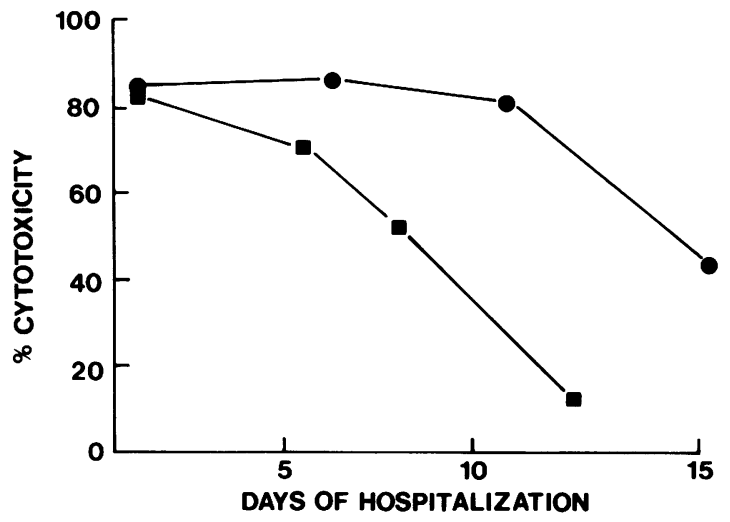

FIGURE 2 NK cell activity during the course of acute EBV infection in two patients with XLP. Case $1(\Theta)$, who received acyclovir on days 2 through 15 and methylprednisolone (5 $\mathrm{mg} / \mathrm{kg}$ per d) on days 12 through 15 ; case $2(\square)$ received acyclovir and methylprednisolone $(5-10 \mathrm{mg} / \mathrm{kg}$ per d) on days 1 through 15 and ATG (15 mg/kg per d) on days 8 through 15. Each point represents mean cytotoxic index at an effector-to-target cell ratio of 50:1. The target cell in each study was the myeloid line K562. 
TABLE III

Lymphocyte Surface Marker Studies in Fatal EBV Infection (Case 2)

\begin{tabular}{cccccc}
\hline & & \multicolumn{4}{c}{ Cell surface markerst } \\
\cline { 3 - 5 } $\begin{array}{c}\text { Day of } \\
\text { study }\end{array}$ & Therapy & OKT.4 & OKT.8 & p23,30 & $\kappa / \lambda$ \\
\hline 1 & None & 3 & 61 & 74 & $17 / 9$ \\
5 & $\begin{array}{c}\text { Methylprednisolone, } 55 \\
\text { mg/kg/d } \times 5 \mathrm{~d}\end{array}$ & 4 & 68 & 98 & $11 / 10$ \\
15 & $\begin{array}{c}\text { Methylprednisolone, } 10 \\
\mathrm{mg} / \mathrm{kg} / \mathrm{d} \times 10 \mathrm{~d} ; \\
\text { ATG } 15 \mathrm{mg} / \mathrm{kg} / \mathrm{d} \times 7 \mathrm{~d}\end{array}$ & 7 & 38 & ND & $50 / 46$ \\
\hline
\end{tabular}

- Therapy, methylprednisolone was given in four divided doses daily; ATG given intravenously in a single dose.

† Results are expressed as percentage of stained cells; OKT.4, helper/inducer T cell subset; OKT.8 cytotoxic/suppressor subset; p23,30, HLA-DR; $\kappa, \lambda$, light chains. ND, not done.

increase in the OKT 8 cytotoxic/suppressor cell subset, most of which expressed HLA-DR antigens as determined by staining with the $\mathrm{p} 23,30$ antisera. Polyclonal $B$ cells were present and 1-2\% of these were infected with EBV as determined by EBNA staining (data not shown). After $5 \mathrm{~d}$ of methylprednisolone therapy, little change in the $T$ cell subsets was apparent. With the addition of ATG, and an increase in the dose of methylprednisolone, the OKT.8 population declined in parallel with the decreased cytotoxic activity (Table II). A marked polyclonal increase in B lymphocytes was noted with $>50 \%$ of peripheral blood lymphocytes (PBL) expressing $\kappa$ or $\lambda$ light chains. The lymphocyte count was $7,500 / \mathrm{mm}^{3}$, reflecting a markedly increased absolute B lymphocyte count.

Autologous cell lines were obtained following the death of case 2 and these cells were utilized as targets in a cytotoxicity assay. Effector cells included previously frozen PBL and a $T$ cell population that was expanded using lectin-free purified $T$ cell growth fac- tor (TCGF). Results are shown in Table IV. Both unexpanded PBMC and TCGF purified T cell populations showed significant cytotoxicity against autologous EBV-infected B cells, fibroblasts, and hepatocyte target cells. Surface marker analysis of the effector cell population showed them to express the OKT.8 antigen and characterization of this population with the monoclonal antibody HNK-1, which recognizes a human NK cell (23), showed that one-third of the OKT.8 population expressed this antigen.

Virological studies. Acute EBV infection was well documented in each case by serology and demonstration of virus-infected B lymphocytes (Table V). Both patients were seronegative before the onset of fatal infectious mononucleosis and developed characteristic antibody responses observed in the acute phase of EBV infection: VCA IgG and IgM, EA antibodies, and absent EBNA antibodies. Spontaneous EBV-infected LCL were obtained from both patients. EBV-infected cells were demonstrated in lymph-node preparations

TABLE IV

T Cell-mediated Cytotoxicity against Autologous Tissues in Fatal EBV Infection (Case 2)

\begin{tabular}{|c|c|c|c|c|c|c|c|}
\hline \multirow[b]{2}{*}{ Cells• } & \multicolumn{4}{|c|}{ Reactivity with monoclonal antibodies! } & \multicolumn{3}{|c|}{ Autologous target cells $\S$} \\
\hline & T101 & OKT.4 & OKT.8 & HNK-1 & EBV + LCL & Fib & Hep \\
\hline & \multicolumn{4}{|c|}{$\%$} & \multicolumn{3}{|c|}{$\%$} \\
\hline PBL, day 1 & 20 & 3 & 61 & ND & 18 & ND & 18 \\
\hline T cell culture, day 5 & 100 & $\mathbf{0}$ & 100 & 32 & 28 & 20 & ND \\
\hline
\end{tabular}

- Cells studied included PBL obtained on day 1 of hospitalization and a bulk T cell culture expanded from day $5 \mathrm{PBL}$ with purified interleukin 2.

I Monoclonal antibodies include T101 (pan-T cell): OKT.4 (inducer/helper); OKT.8 (cytotoxic/suppressor); HNK-1 (see Methods for further details). ND, not done.

\$ Autologous target cells include EBV + LCL, spontaneous EBV-infected LCL; Fib, fibroblasts; Hep, hepatocytes. Results are expressed as cytotoxic index at an effector-to-target cell ratio of 25:1. 
TABLE V

Virologic Studies of Two Males with XLP and Fatal EBV Infection

\begin{tabular}{|c|c|c|c|c|c|}
\hline \multirow[b]{2}{*}{ Time of study } & \multicolumn{3}{|c|}{ EBV antibody titers } & \multirow{2}{*}{$\begin{array}{l}\text { Spontaneous } \\
\text { EBV + LCL }\end{array}$} & \multirow[b]{2}{*}{ EBNA + cells $\downarrow$} \\
\hline & VCA (IgM) & EA & EBNA & & \\
\hline \multicolumn{6}{|l|}{ Case 1} \\
\hline Preinfection & $<1: 10$ & $<1: 10$ & $<1: 10$ & ND & ND \\
\hline Day 1 hospital & $1: 80(1: 320)$ & $1: 20$ & $<1: 10$ & + & +Lymph node \\
\hline Day 12 (after gamma globulin) & $1: 160(1: 40)$ & $1: 20$ & $1: 10$ & + & ND \\
\hline Day 16 & $1: 80(1: 20)$ & $<1: 10$ & $1: 10$ & + & $\begin{array}{l}+ \text { (thymus, lymph node } \\
\text { spleen, liver })\end{array}$ \\
\hline \multicolumn{6}{|l|}{ Case 2} \\
\hline Preinfection & $<1: 10$ & $<1: 10$ & $<1: 10$ & - & ND \\
\hline Day 1 hospital & $1: 160(1: 160)$ & $1: 160$ & $<1: 5$ & + & $+($ Blood $)$ \\
\hline Day 4 (after gamma globulin) & ND & ND & ND & + & ND \\
\hline Day 15 & ND & ND & ND & + & $\begin{array}{c}+ \text { (Blood, spleen, liver, } \\
\text { lymph node })\end{array}$ \\
\hline
\end{tabular}

- ND, not done.

- $\mathrm{EBV}=$ positive cell line established.

$\downarrow \mathrm{EBNA}=$ positive cells.

of case 1 and PBL of case 2 by demonstration of EBNA. $A$ peripheral blood smear from case 2 stained for EBNA is shown in Fig. 3, where $40-50 \%$ of the cells are positive. This specimen was obtained on the last day of life. Autopsy revealed extensive lymphoproliferation and the liver was massively infiltrated with immunoblasts. A touch preparation of liver tissue stained for EBNA is shown in Fig. 4. Large numbers of EBNA-containing cells were easily demonstrated. Peripheral blood samples obtained late in the course of the illness were studied for evidence of productive virus infection. Smears of EBNA-positive B lymphocytes did not demonstrate the presence of VCA or EA, indicating that mature virus was not being produced. Studies performed on tissues obtained from postmortem samples of case 2 revealed extensive infiltration of spleen, lymph nodes, thymus, and liver with EBNApositive cells. Hepatocyte cultures were obtained from small pieces of liver tissue and these cells were stained and found to be EBNA negative. Molecular hybridization studies performed on lymphoreticular tissues in each case demonstrated EBV genome in whole tissue DNA preparations. ${ }^{2}$ Spontaneous lymphoblastoid cell lines from cases 1 and 2 were checked for evidence of productive EBV infection by assaying culture supernatants for the presence of transforming virus. In each case, transforming EBV was not present in culture supernatants. Expression of lymphocyte-determined

\footnotetext{
${ }^{2}$ Sullivan, J. L., S. M. Baker, and C. Mulder. Unpublished observation.
}

membrane antigen, by spontaneous LCL from cases 1 and 2, was assayed by using these cell lines as target cells with cytotoxic effector cells derived from normal individuals in the acute phase of infectious mononucleosis. In each case, the spontaneous EBV-infected LCL were lysed to a similar degree as standard target cells used in these assays (12). Lymphocyte preparations from each patient were challenged with Newcastle disease virus and Con $A$ to induce alpha and gamma interferon production and found to be normal (data not shown).

\section{Immunological studies in surviving males after acute $E B V$ infection}

Cellular and humoral immune studies performed on cases $3,4,5$, and 6 are summarized in Table VI. Lymphocyte surface marker analysis revealed relatively normal percentages of $T$ and $B$ lymphocytes. Enumeration of lymphocyte subsets demonstrated increased numbers of the OKT.8 (cytotoxic/suppressor) $T$ cell subset. Lymphocyte populations identified with the monoclonal antibodies HNK.1 and OKM.1, both of which react with human NK cell populations, were normal. Assessment of quantitative immunoglobulins showed each individual to have abnormalities of one isotype and two of the four cases meet the criteria for the diagnosis of common variable immunodeficiency with normal numbers of $B$ lymphocytes and decreased IgG levels. Lymphocyte proliferative responses to graded amounts of mitogens and antigens were abnormal in each of the four cases, with $T$ cell prolif- 


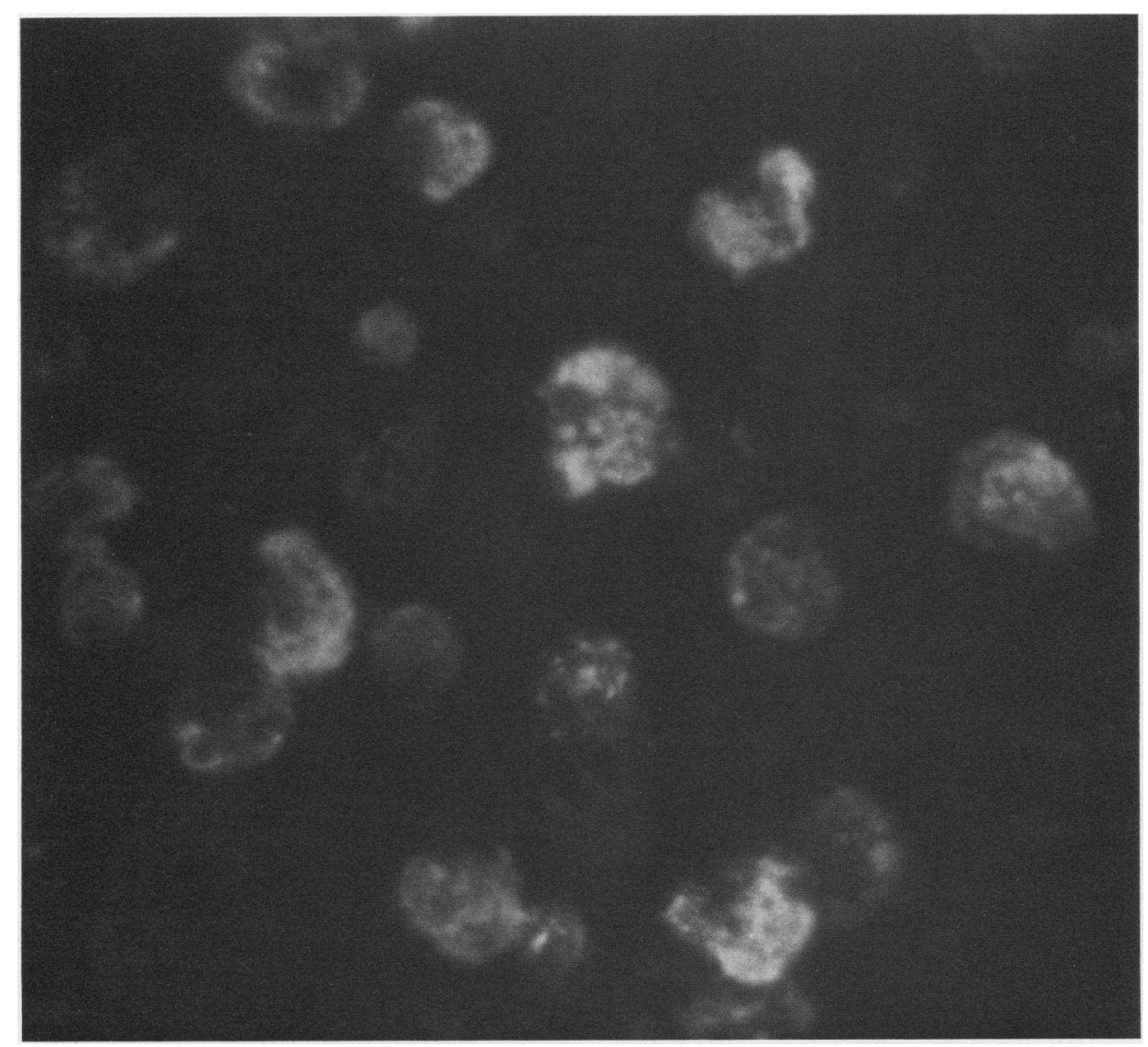

Figure 3 Case 2, PBMC stained for EBNA $(\times 400)$.

eration being abnormal in all four and B cell proliferation being normal in three of four. In each individual studied, previous exposure to EBV was proved by one or more of the following criteria: history of infectious mononucleosis with positive heterophile antibody, establishment of an EBNA-positive LCL and presence of EBV-specific antibodies. Case 3 and 4, who have hypogammaglobulinemia, show very low levels of EBV VCA antibodies. Both of these individuals are receiving monthly gamma globulin therapy, which probably accounts for these low EBV antibody levels.

NK cell activity was decreased in three of the four cases each effector-to-target cell ratio (13). Interferon treatment of effector cells resulted in small increases in cytotoxicity, but normal activity was never achieved. NK cell activity against herpes simplex virus-infected target cells (14) was tested in case 3 and case 4 and found to be depressed below normal (data not shown).

In an attempt to evaluate antibody production to specific antigens, we intravenously immunized three of the four cases with bacteriophage $\phi \times 174$. These results are shown in Fig. 5. Two of three responded normally to primary immunization and all three showed normal anamnestic responses after secondary immunization. Qualitative assessment of the immune response after secondary immunization revealed all three to be severely deficient in IgG production (case $3,4 \%$; case $4,2 \%$; and case $6,4 \%$ ). Results obtained in 30 normal male individuals showed a mean of $48 \%$ IgG production with a range of 20 to $78 \%$. In summary, immunological studies in four surviving males with XLP following EBV infection have demonstrated global defects that encompass cellular and humoral immune responses.

\section{DISCUSSION}

Immunological studies reported previously in XLP have focused only on affected males who survived the initial encounter with EBV. These studies have demonstrated abnormal antibody responses to EBV (24), NK cell defects (13), and abnormalities in T lymphocyte subsets $(25)$. The results reported here suggest that defective immunoregulation of a subset of cytotoxic 


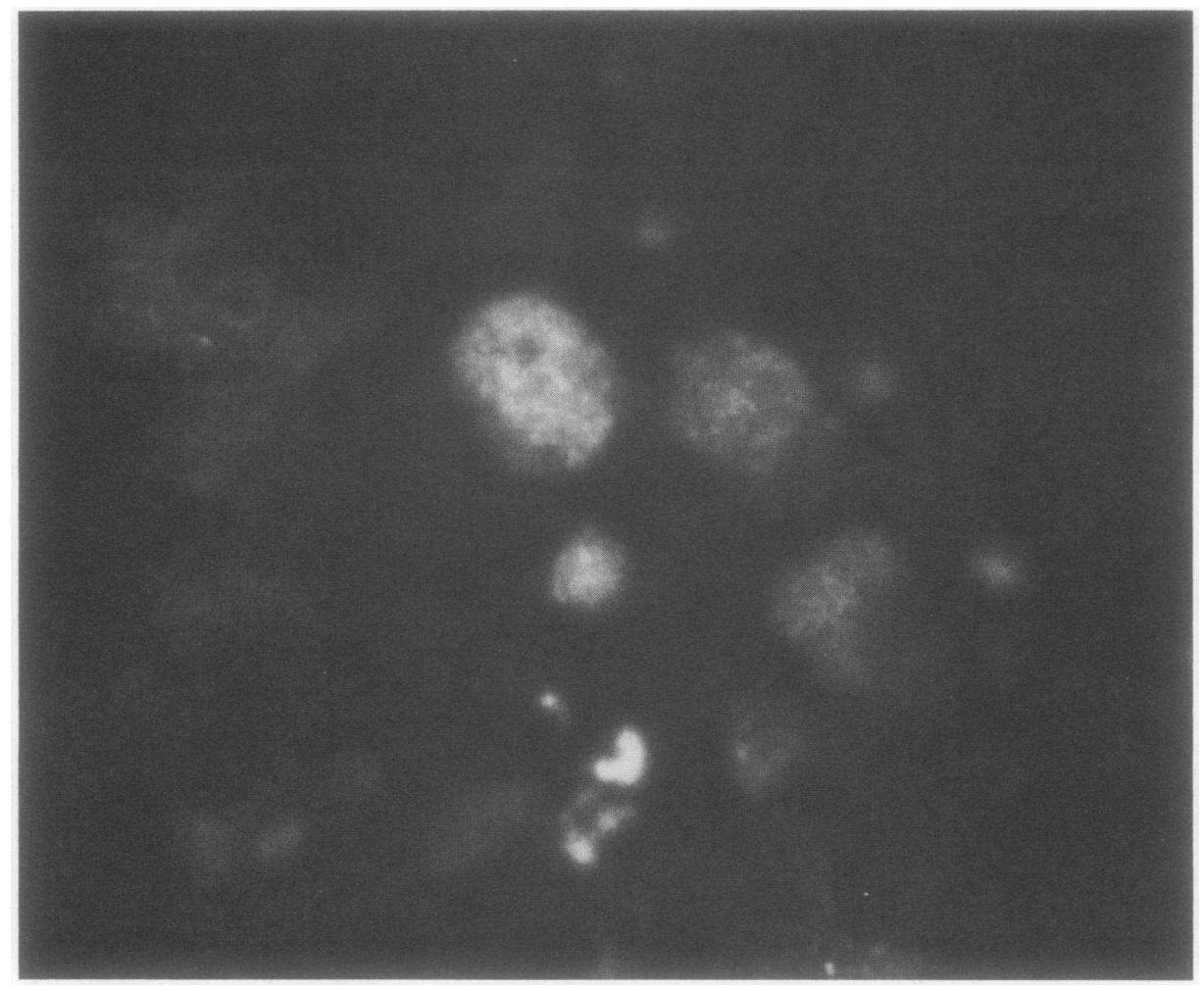

Figure 4 Case 2, liver touch preparation stained for EBNA $(\times 400)$.

T cells, which are not HLA antigen restricted, may contribute to complex and varied clinical outcomes in male individuals with XLP. These data have been derived from the first prospective study of affected males with XLP before and during infection with EBV.

In the first case presented, clinical assessment and screening immunological studies before infection with EBV demonstrated an intact immune system. Normal in vivo responses to viral and bacterial antigens were documented. In vitro $\mathrm{T}$ lymphocyte responses to nonspecific mitogens and antigens were normal, as were B lymphocyte markers and quantitative immunoglobulins. After exposure to EBV, infection and dissemination of EBV-infected B lymphocytes occurred, which initiated a normal humoral response (IgM and IgG antibody against VCA) and a vigorous killer cell response that was directed against a variety of target cells regardless of histocompatibility type and expression of EBV-determined antigens. Coincident with this response was the appearance of hepatitis, which became progressively severe and ultimately caused hepatic necrosis and death. Immunosuppressive agents were not used in this patient until the terminal phases. The presence of cytotoxic cells throughout the course of illness may explain the absence of intense B cell proliferation (12); EBV-infected proliferating B lymphocytes being lysed by the killer-cell response, which also resulted in hepatocytoxicity.

Case 2 was also studied before experience with EBV and demonstrated normal humoral immunity and in vitro $\mathrm{T}$ lymphocyte responses. In addition, cytotoxicity studies revealed normal NK cell activity against the K562 and Daudi targets. Two relevant observations in this patient are the development at age $3.5 \mathrm{yr}$ of a lymphosarcoma of the liver, which was cured with chemotherapy and subsequently at age $6.5 \mathrm{yr}$ the development of uncomplicated varicella infection. It is unlikely that this patient's lymphoma was associated with EBV infection since at age $8 \mathrm{yr}$, when first studied by us, he lacked EBV antibody and a spontaneous EBV-infected LCL could not be established. Uncomplicated varicella infection is further evidence of normal immune function before acute EBV infection.

Cases 1 and 2 provide strong evidence that the immunological defect in XLP is limited to or triggered by infection with EBV. Cytotoxic cells were present in the peripheral blood of each patient during infection. These cytotoxic cells killed EBV-infected LCL, as well as fibroblasts. Killing of autologous hepatocytes was also observed in case 2 and suggest that the hep- 
TABLE VI

Immunological Assessment in Four Surviving Males with XLP following EBV Infection

\begin{tabular}{|c|c|c|c|c|c|}
\hline & Case $3^{\bullet}$ & Case $4^{\circ}$ & Case 5 & Case 6 & Normal controls \\
\hline \multicolumn{6}{|l|}{ Lymphocyte surface markers (\%) } \\
\hline T lymphocytes & 69 & 55 & 54 & 63 & $65 \pm 2.9$ \\
\hline Inducer (OKT.4) & 49 & 27 & ND & 52 & $41 \pm 2.8$ \\
\hline Cytotoxic/Suppressor (OKT.8) & 43 & 42 & ND & 41 & $28 \pm 3$ \\
\hline B lymphocytes & 8 & 10 & 13 & 6 & $10.5 \pm 0.7$ \\
\hline NK cells (HNK-1) & 32 & 24 & ND & 30 & $12.3 \pm 5.1$ \\
\hline Monocytes and NK cells (OKM.1) & 18 & 32 & ND & 21 & $19.0 \pm 2.5$ \\
\hline \multicolumn{6}{|l|}{$\begin{array}{l}\text { Quantitative immunoglobulins }(\mathrm{mg} / \\
\qquad 100 \mathrm{ml} \text { ) }\end{array}$} \\
\hline IgG & 450 & 260 & 1,138 & 640 & $635-1,775$ \\
\hline $\operatorname{Ig} A$ & 32 & 22 & 59 & 13 & $106-668$ \\
\hline IgM & 14 & 40 & 44 & 103 & $37-154$ \\
\hline \multicolumn{6}{|l|}{ Lymphocyte proliferation studies $\ddagger$} \\
\hline PHA & 45,590 & 58,845 & 66,241 & 67,396 & $71,450-82,414$ \\
\hline CON A & 98,624 & 129,297 & 135,907 & 24,885 & $81,847-106,414$ \\
\hline PWM & 19,887 & 28,676 & 62,548 & 15,664 & $27,164-38,194$ \\
\hline MLR & 59,845 & 73,756 & 182,207 & ND & $153,460-181,130$ \\
\hline $\mathrm{S} / \mathrm{O}$ & 30,041 & 48,302 & 163,683 & 25,091 & $41,495-75,858$ \\
\hline Anti-Ig & 31,587 & 57,331 & 59,546 & 5,090 & $5,248-11,803$ \\
\hline \multicolumn{6}{|l|}{ Cytotoxicity studies§ } \\
\hline Target K562 & $24 \%$ & $79 \%$ & $5 \%$ & $31 \%$ & $50-100 \%$ \\
\hline 8392 & $6 \%$ & $0 \%$ & $0 \%$ & $0 \%$ & $0-10 \%$ \\
\hline \multicolumn{6}{|l|}{ EBV Serology" } \\
\hline VCA & $1: 20$ & 1:10 & $1: 320$ & $1: 640$ & \\
\hline EA & $<1: 10$ & $<1: 10$ & $1: 40$ & $<1: 10$ & \\
\hline EBNA & $>1: 5$ & $<1: 5$ & $<1: 2$ & $<1: 5$ & \\
\hline
\end{tabular}

- Case 3 and 4 are receiving monthly gamma globulin injections.

† Results expressed as mean counts per minute of triplicate cultures which showed maximal stimulation to graded doses of mitogens and antigens; MLR, using a B lymphoblastoid cell line as a stimulator; S/O streptolysin O. Normal values represent $95 \%$ confidence interval from 17 normal young adults.

\$ Cytotoxicity studies were performed at an effector-to-target cell ratio of 50:1 in a 4-h chromium release assay. Results are expressed as a cytotoxic index (Methods). K562 is a myeloid target sensitive to NK cell activity and 8392 is an EBV-infected B lymphoblastoid cell sensitive to EBV-specific T cell-mediated cytotoxicity.

atitis occurring during EBV infection in individuals with XLP may be secondary to anomalous killing. Killer cells also showed activity against autologous lymphoblasts and fibroblasts. There was no evidence for HLA preference between effector cells and target cells. EBV infects and replicates strictly in B lymphocytes under normal circumstances (26). Infection of $B$ cells results in transformation to lymphoblastoid immunoglobulin-secreting cells (27). EBV-infected lymphoblasts express viral-determined antigens (i.e., lymphocyte-determined membrane antigen), as well as poorly characterized blast cell antigens which are potent polyclonal stimulators of autologous or allogeneic $T$ lymphocytes $(11,27)$. Polyclonal $T$ cell responses to EBV-infected B LCL are not dependent on previous sensitization with EBV antigens. The atypical lymphocytosis characteristic of infectious mononucleosis includes cytotoxic $\mathrm{T}$ cells that kill EBV-infected lymphoid targets in the absence of shared HLA antigens (12). This cytotoxic $T$ cell response is nonclassical, in that recognition of shared HLA antigens between the effector and target cells are not required, as prescribed in the Doherty-Zinkernagel model (29). HLA-restricted cytotoxic $\mathrm{T}$ cells have been demonstrated in vivo during influenza (30), acute cytomegalovirus (31), and mumps (32) infections in man. Nonclassical T cellmediated cytotoxicity has recently been described in several in vitro systems. Originally termed anomalous killer (AK) cells, these cytotoxic $\mathrm{T}$ cells, which kill several types of target cells including fresh tumor cells, 


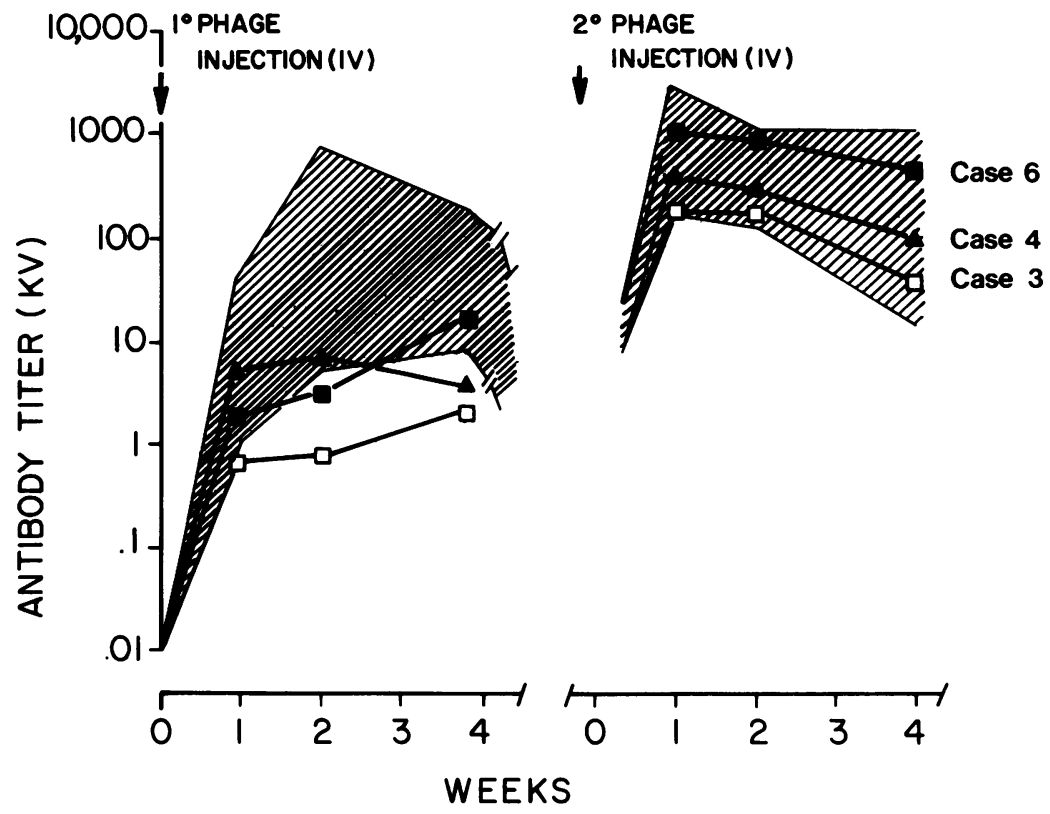

FIGURE 5 Antibody responses to two injections of bacteriophage $\phi \times 174$ given intravenously. The shaded area indicates the range of normal control. Antibody responses of three XLP patients are indicated individually.

can be generated during alloactivation (33), coculture with tumor cells (34), or innoculation with Interleukin 2 (35). Recent cell-surface marker analysis of AK cells has shown them to bear the pan-T cell marker and the OKT.8 antigen (35). Abo et al. $(36,37)$ have recently shown that AK cells can be discriminated from NK cells. AK cells do not express the HNK-1 antigen which is found on NK cells. The observed cytotoxic responses in two patients with XLP experiencing acute EBV infection could be the result of two populations of cytotoxic T cells: AK cells $\left(\mathrm{T}^{+} \mathrm{HNK}^{-} \mathrm{I}^{-}\right)$and $\mathrm{NK}$ $\left(\mathrm{T}^{+}{ }^{+} \mathrm{HNK}-1^{+}\right)$cells. Furthermore, these cytotoxic cells were found to have anti-"self" activity. Fulminant liver failure with hepatic necrosis is an important cause of death in XLP. We have demonstrated that cytotoxic $T$ cells obtained from patients with XLP can lyse autologous primary hepatocytes. It appears from our studies that cytotoxic $T$ cells induced during acute EBV infection are relatively resistant to high doses of corticosteroids. This is in contrast to the relative sensitivity of NK cells in vivo corticosteroid administrations (reviewed in reference (38).

Studies in four surviving male members of the same kindred years after acute EBV infection have demonstrated multiple defects in the immune system. All have demonstrated some abnormality in the quantitative immunoglobulin levels and two of these individuals are on monthly gamma globulin injections. These two individuals have suffered increased numbers of bacterial infections (predominantly pulmonary) and have done well on gamma globulin therapy. Each of these individuals has demonstrated one or more of the following abnormalities: normal total numbers of $T$ lymphocytes but increased numbers of OKT.8-bearing cells. Depressed responses to $T$ cell mitogens and antigens and deficient NK cell activity to K562, Daudi, and herpes simplex virus-infected target cells. Normal augmentation of NK cell activity with interferon is absent. Immunizations with bacteriophage $\phi \times 174$ antigen have demonstrated near normal primary and secondary immune responses, but only small amounts of IgG antibody are produced after secondary immunization. These findings suggest global defects in $T$ and NK cell function.

Normal immune function before infection with EBV in affected males with XLP and demonstration of major defects in the immune system of surviving affected males is strong evidence for an aberrant immune response specifically triggered by EBV. Our studies have not demonstrated a deficiency in any cellular or humoral response normally observed during acute EBVinduced infectious mononucleosis in normal individuals $(12,13,21)$. In addition, we have not observed any abnormality in the virus-B lymphocyte relationship, i.e., increased production of infectious virus, or resistance to killing by cytotoxic $\mathrm{T}$ cells. We have observed what appears to be an uncontrolled activation of anomalous and NK cells that can mediate lysis of 
autologous lymphoid and nonlymphoid targets. Our findings are consistent with the hypothesis that uncontrolled AK and NK activity results in fatal infectious mononucleosis or immune deficiency in those affected males surviving acute EBV infections. This mechanism would explain the variation in the severity of the immune deficiency observed within affected kindreds $(3,4)$. These secondary immune deficits may predispose surviving males with XLP to increased numbers of bacterial infections and perhaps to lymphoreticular malignancies. Further studies are in progress to determine normal regulatory mechanisms for $\mathrm{AK}$ and NK cells activated during acute EBV-induced infectious mononucleosis in normal individuals. These studies may be helpful in our understanding of acquired immune deficiency in man.

\section{ACKNOWLEDGMENTS}

We would like to thank Dr. E. Kaplan and Dr. E. Bailey for referring cases 1 and 2 and providing medical records. Drs. K. Muralidharan, B. Kashanchi, J. Krolikowski, and B. Woda are thanked for the interpretation of autopsy data and providing sterile tissues for analysis. Additional thanks are extended to Ms. Nancy Radzik and members of the Word Processing Center for secretarial support.

This work was supported by grant AI 18255-01 from the National Institutes of Health and a grant from the Burroughs Wellcome Company. Dr. Sullivan is a Fellow of the Charles A. King Trust, Boston, MA.

\section{REFERENCES}

1. Bar, R. S., C. J. Delor, K. P. Clausen, P. Hurtubise, W. Henle, and J. F. Heweston. 1974. Fatal infectious mononucleosis in a family. N. Engl. J. Med. 290: 363-367.

2. Provisor, A. J., J. J. Iacuone, R. R. Chilcote, R. G. Neiburger, F. G. Crussi, and R. L. Baehner. 1975. Acquired agammaglobulinemia after a life-threatening illness with clinical and laboratory features of infectious mononucleosis in three related male children. N. Engl. J. Med. 293: 62-65.

3. Purtilo, D. T., J. P. Yang, C. K. Cassel, R. Harper, S. R. Stephenson, B. H. Landing, and G. F. Vawter. 1975. Xlinked recessive progressive combined variable immunodeficiency. Lancet. I: 935-940.

4. Hamilton, J. K., L. Paquin, J. Sullivan, H. Maurer, F. Cruzi, A. Provisor, P. Steuber, E. Hawkins, D. Yawn, J. Cornet, K. Clausen, G. Finkelstein, B. Landing, M. Grunnet, and D. Purtilo. 1980. X-linked lymphoproliferative syndrome registry report. J. Pediatr. 96: 669673.

5. Purtilo, D. T., D. DeFloria, Jr., L. Hutt, J. Bhawan, J. Yang, R. Otto, and W. Edwards. 1977. Variable phenotypic expression of an X-linked recessive lymphoproliferative syndrome. N. Engl. J. Med. 297: 1077-1081.

6. Sullivan, J. L., K. S. Byron, F. E. Brewster, K. Sakamoto, J. E. Shaw, and J. S. Pagano. 1982. Treatment of life threatening Epstein-Barr virus infections with acyclovir. Am. J. Med. 73: 262-266.

7. Kaighn, M. E. 1973. Human liver cells. In Tissue Culture: Methods and Applications. P. F. Kruse and M. K.
Patterson, editors. Academic Press, Inc., New York. 5458.

8. Winchester, R. J., and G. Ross. 1980. Methods for enumerating lymphocyte populations. In Manual of Clinical Immunology. N. R. Rose and H. Friedman, editors. American Society for Microbiology, Wash., DC. 213228.

9. Oppenheim, J. J., and B. Schecter. 1980. Lymphocyte transformation. In Manual of Clinical Immunology. N. R. Rose and H. Friedman, editors. American Society for Microbiology, Wash., DC. 233-245.

10. Fothergill, J. J., R. Wistar, J. N. Woody, and D. C. Parker. 1982. A mitogen for human B cells: anti-Ig coupled to polyacrylamide beads activates blood mononuclear cells independently of $T$ cells. J. Immunol. 128: 19451949.

11. Sullivan, J. L., H. D. Ochs, and R. J. Wedgwood. 1982. In vitro responses to a B-lymphoblastoid cell line in immunodeficiency diseases. J. Clin. Immunol. 2: 150-155.

12. Royston, I., J. L. Sullivan, P. O. Periman, and E. Perlin. 1975. Cell-mediated immunity to Epstein-Barr virustransformed lymphoblastoid cells in acute infectious mononucleosis. N. Engl. J. Med. 293: 1159-1163.

13. Sullivan, J. L., K. S. Byron, F. E. Brewster, and D. T. Purtilo. 1980. Deficient natural killer cell activity in the $\mathrm{X}$-linked lymphoproliferative syndrome. Science (Wash. DC). 210: 543-545.

14. Ching, C., and C. Lopez. 1979. Natural killing of herpes simplex virus type I-infected target cells: normal human responses and influence of antiviral antibody. Infect. Immun. 26: 49-56.

15. Wedgwood, R. J., H. D. Ochs, and S. D. Davis. 1975. The recognition and classification of immunodeficiency diseases with bacteriophage OX 174. In Immunodeficiency in Man and Animals. D. Bergsma, editor. The National Foundation-March of Dimes Birth Defects: Original Article Series, Vol. XI, No. 1, Sinauer Associates, Inc., Sunderland, MA. 331-338.

16. Sullivan, J. L., H. D. Ochs, G. Schiffman, M. R. Hammerschlag, J. Miser, E. Vichinsky, and R. J. Wedgwood. 1978. Immune response after splenectomy. Lancet. I: 178-180.

17. Henle, W., G. Henle, and C. A. Horowitz. 1979. Infectious mononucleosis and Epstein-Barr virus-associated malignancies. In Diagnostic Procedures for Viral, Rickettsial, and Chlamydial Infections. E. H. Lennette and N. J. Schmidt, editors. American Public Health Association, 5th edition. 441-470.

18. Reedman, B. M., and G. Klein. 1973. Cellular localization of an Epstein-Barr virus-associated complement-fixing antigen in producer and nonproducer lymphoblastoid cell lines. Int. J. Cancer. 11: 499-520.

19. Nilsson, K. 1976. Establishment of permanent human lymphoblastoid cell lines in vitro. In In Vitro Methods in Cell-Mediated and Tumor Immunity. B. R. Bloom and J. R. David, editors. Academic Press, Inc., New York. 713-721.

20. Colby, B. M., J. E. Shaw, G. B. Elion, and J. S. Pagano. 1980. Effect of acyclovir [9-(2-hydroxyethoxymethyl)guanine] on Epstein-Barr virus DNA replication. $J$. Virol. 34: 560-568.

21. Mangi, R. J., J. C. Niederman, J. E. Kelleher, J. M. Dwyer, A. S. Evans, and F. S. Kantor. 1974. Depression of cell-mediated immunity during acute infectious mononucleosis. N. Engl. J. Med. 291: 1149.

22. Seeley, J., E. Svedmyr, O. Weiland, G. Klein, E. Moller, E. Eriksson, K. Andersson, and L. Van Der Waal. 1981. 
Epstein Barr virus selective $\mathrm{T}$ cells in infectious mononucleosis are not restricted to HLA-A and B antigens. J. Immunol. 127: 293-300.

23. Abo, T., and C. M. Balch. 1981. A differentiation antigen of human NK and $\mathrm{K}$ cells identified by a monoclonal antibody (HNK-1) ${ }^{1}$. J. Immunol. 127: 1024-1029.

24. Sakamoto, K., H. J. Freed, and D. T. Purtilo. 1980. Antibody responses to Epstein-Barr virus in families with the X-linked lymphoproliferative syndrome. J. Immunol. 125: 921-925.

25. Seeley, J. K., K. Sakamoto, S. Ip, P. Hansen, and D. T. Purtilo. 1981. Abnormal subjects of $T$ cells in the $X$ linked lymphoproliferative syndrome. J. Immunol. 127: 2618-2620.

26. Robinson, J., D. Smith, and J. Niederman. 1980. Mitotic EBNA-positive lymphocytes in peripheral blood during infectious mononucleosis. Nature (Lond.). 287: 334-335.

27. Bird, A. G., S. Britton, I. Ernberg, and K. Nilsson, 1981. Characteristics of Epstein-Barr virus activation of human B lymphocytes. J. Exp. Med. 154: 832-839.

28. Ernberg, I. L., and G. Klein. 1979. EBV-induced antigens. In The Epstein-Barr Virus. M. A. Epstein and B. G. Achong, editors. Springer-Verlag, Heidelberg. 3960 .

29. Doherty, P. C., and R. M. Zinkernagel. 1974. T-cellmediated immunopathology in viral infections. Transplant. Rev. 19: 89-120.

30. Ennis, F. A., W. Y. Hua, D. Riley, A. H. Rook, G. C. Schild, R. Pratt, and C. W. Potter. 1981. HLA-restricted virus-specific cytotoxic $\mathrm{T}$-lymphocyte responses to live and inactivated influenza vaccines. Lancet. II: 887-891.

31. Quinnan, G. V., N. Kirmani, A. H. Rook, J. F. Manischewitz, L. Jackson, G. Moreschi, G. W. Santos, R. Saral, and W. Burns. 1982. Cytotoxic T cells in cytomegalovirus infection. N. Engl. J. Med. 307: 6-13.

32. Kreth, H. W., L. Kress, H. G. Kress, H. F. Ott, and G. Eckert. 1982. Demonstration of primary cytotoxic T cells in venous blood and cerebrospinal fluid of children with mumps meningitis. J. Immunol. 128: 2411-2415.

33. Seeley, J. K., and S. H. Golub. 1978. Studies on cytotoxicity generated in human mixed lymphocyte cultures. I. Time course and target spectrum of several distinct concomitant cytotoxic activities. J. Immunol. 120: 1415.

34. Vankey, F., T. Gorsky, Y. Gorsky, M. G. Masucci, and E. Klein. 1982. Lysis of tumor biopsy cells by autologous $T$ lymphocytes activated in mixed cultures and propagated with T cell growth factor. J. Exp. Med. 155: 8395.

35. Grimm, E. A., A. Mazumder, H. Zhang, and S. Rosenberg. 1982. Lymphokine-activated killer cell phenomenon. Lysis of natural killer-resistant fresh solid tumor cells by interleukin 2-activated autologous human peripheral blood lymphocytes. J. Exp. Med. 155: 18231841.

36. Abo, T., M. D. Cooper, and C. M. Balch. 1982. Characterization of HNK-1 (Leu-7) human lymphocytes. I. Two distinct phenotypes of human NK cells with different cytotoxic capability. J. Immunol. 129: 1752-1757.

37. Abo, T., and C. M. Balch. 1982. Characterization of HNK-1 (Leu-7) human lymphocytes. II. Distinguishing phenotypic and functional properties of natural killer cells from activated NK-like cells. J. Immunol. 129: 1758-1761.

38. Cupps, T. R., and A. S. Fauci. 1982. Corticosteroid-mediated immunoregulation in man. Immunol. Rev. 65: 134-155. 